\title{
H. H. W. Pearson, F.R.S., Sc.D. (Cambridge).
}

BY

\section{A. C. SEWARD.}

$\mathrm{H}^{\mathrm{s}}$ ENRY HAROLD WELCH PEARSON was born at Long Sutton, Lincolnshire, on January 28,1870 , and died on November 3, I9I6, at the Mount Royal Hospital, Wynberg, Cape Town. He had been ill for several weeks, and after recovering from the effects of an operation for haemorrhoids he contracted pneumonia, which caused his death : it is suggested by the author of an obituary notice in the 'South African College Magazine' that an attack of malaria in I9I3 in Portuguese West Africa was the beginning of the undermining of his never very robust health. His widow writes : 'Most of us feel that the strain of the College and Garden work had been too much for him, and when pneumonia attacked him he had not sufficient strength to fight against it.' When Pearson was about eight years old his father went to live at Wickhambrook, Suffolk, where he kept a boys' school, and here the son received part of his education: he was for a short time a boarder at a school at Beccles. On leaving school it was arranged that he should begin his career as a chemist's assistant at Hawkhurst; the work was uncongenial, but his employer spoke of him as the best assistant he had ever had. By judicious use of his spare time Pearson was able to pass the London Matriculation examination, and shortly afterwards he was appointed assistant master at Mr. Waite's school at Eastbourne, where he remained about four years. In a recent letter to Mrs. Pearson the Head Master's sister wrote: 'He did a great deal of studying, and we were particular about the boys keeping quiet and away from his study during the evenings ; we all just loved him.' He obtained a Clothworkers' Exhibition and entered the University of Cambridge as a Non-Collegiate student in I893. He obtained a First class in both parts of the Natural Sciences Tripos (1896-7). In October, I 96, after taking his Bachelor's degree, he entered Christ's College and was elected Scholar in the following June. In the same year he went to Ceylon with the assistance of a grant of $£ \mathrm{I} 00$ from the Cambridge University Worts Travelling Fund, the additional cost of the visit being generously defrayed, as Pearson states in his account of the Ceylon work, by his very good friend the Rev. Herbert Alston, formerly Rector of Little Bradley,




Studentship, he became a member of Gonville and Caius College. $\mathrm{He}$ was appointed Assistant Curator of the Cambridge Herbarium in 1898 , and in 1899 he was awarded the Walsingham Medal for his work on the vegetation of the Ceylon patanas. He was appointed Assistant (for India) in the Herbarium of the Royal Gardens, Kew, in I 899, and two years later was transferred to the Director's office. In 1903 Pearson was elected to the Harry Bolus Professorship of Botany at the South African College, Cape Town, and took up his duties in April of that year. The relations between Dr. Harry Bolus and the first occupant of the chair bearing his name were always most cordial. The confidence felt by the older man for the younger, and expressed in many acts of kindness, was repaid by the respect and affection which he received in return. In a biographical sketch of Dr. Bolus Pearson described him as 'a man who, one would think, almost unknown to himself, has played a great part in the establishment of Botany as a science in South Africa', a description that would also apply to the writer of these words. In I9I5, under the editorship of Pearson, the Cambridge University Press published the first part of the 'Annals of the Bolus Herbarium', a periodical devoted primarily to work inspired directly or indirectly by Dr. Bolus, and to investigations conducted in or in connexion with the Bolus Herbarium. He was also editor of the 'Journal of the Botanic Society of South Africa', a Society of which he was one of the most active members.

Before leaving England Pearson married Ethel, the youngest daughter of the late William Pratt, of Little Bradley, Suffolk. He took the Cambridge Sc.D. degree in 1907, and in I916 was elected a Fellow of the Royal Society.

In the following sketch I have quoted freely from a series of letters in my possession in order to enable the reader to come into intimate relation with Pearson's singularly attractive personality. He combined the qualifications of the best type of student with the wisdom of the man of affairs; capable in organization, an original thinker, and a warm-hearted friend. He retained the enthusiasm and brightness of youth, and his uniform courtesy and tact made him popular with all who knew him. His influence as a botanist extended far beyond the ranks of his professional colleagues. It would be difficult to estimate at its true value the services he rendered to South A frica. He was a successful and stimulating teacher ; his own keenness in research gave reality to his lectures, and through his influence several of his pupils came to Cambridge to continue investigations which he had suggested. The place he occupied in the hearts of his students is illustrated by the following extracts from letters written to his widow: 'He was our best and truest friend, for we had learnt to look to him for guidance and counsel in all matters of importance.' 'Those of us who had the privilege of working under him feel that it is an honourable 
duty to help carry on the manifold activities which he had set in motion and bequeathed to the world.' 'I shall always count it one of my greatest privileges to have been one of his students.' 'We have known the full benefit of his happy knack of infusing energy into every one he inspired, and we have been brought by him into a truer, more idealistic appreciation of science for science's sake. A teacher-friend, we mourn an all-round loss.'

Pearson played a leading part in the foundation of the National Garden at Kirstenbosch, which in the hands of competent successors should become one of the finest in the world.

My first meeting with Pearson was in 1892 at Eastbourne as a student attending a course of lectures on 'Plant Life' which I was delivering as a University Extension Lecturer. During rambles on the shore in search of seaweeds he discussed with me the possibility of realizing his ambition to come to Cambridge, and from that time onwards it was my privilege to enjoy his friendship. In a letter written on April 4, I916, after hearing of his election to the Royal Society, Pearson recalled the Eastbourne days : ' I was a little surprised to find myself in the list this year: that I was pleased needs no statement. Under any circumstances I should appreciate the honour immensely; under my particular circumstances I think I value it more than I should under some others-isolated here from the centre of the things that interest me, this distinction means a very great deal to me. I hope I deserve it. I am not quite sure, though I am grateful to you and others for saying and thinking that I do.... I regard this as an outcome of those... lectures you gave at Eastbourne-but for them where I should have been I do not know, but I certainly should not have been here and almost certainly the Council of the Royal Society would never have heard of me.'

Writing from Kew after his appointment to the South African chair he said: 'I have always been fond of teaching. I even liked it when we made our Polysiphonia excursions at Eastbourne. I have had very valuable experience here, for which I believe I am the better. I certainly know more of systematic, economic, and administrative work than when I left Cambridge, and if I have become a bit rusty in some of the other branches I think the defects will not be difficult to remedy.' His subsequent career demonstrated the value of his early training. He was always thoughtful of others, and expected those associated with him to do their share not only in teaching, but in the investigation of the numerous problems awaiting solution. In a letter asking for the names of possible men for an assistantship he added, 'He must do research work, for which he will have as much time as I have'.

At one time when the financial outlook in Cape Colony was far from bright and the College was compelled to reduce the staff and the stipends of professors, and because family affairs in England required attention, he 
seriously thought of returning to England. He was an applicant for the Botanical chair at Leeds: "My disappointment with regard to the Leeds post has been a thing of the past for some weeks.... That they should insist on seeing a man before appointing him is obviously reasonable, and were I on an appointment committee I should take the same line.... As long as I am here I can at least do spade-work in research' (July 30 , I907).

Pearson's first published paper deals with the anatomy of the seedling of the Queensland Cycad Bowenia, a straightforward piece of work carried out in the Cambridge Laboratory and undertaken, as I well remember, with characteristic keenness. He was always specially interested in the Cycads and contributed many important additions to our knowledge of the South African representatives of the family, not only directly by his own observations in the field, but by stimulating others more favourably situated geographically than he was for making regular records bearing on the phenomena connected with pollination, and by sending material to England. 'I have to-day', he wrote on June II, I906, 'got a little more light on the pollination question. One of my helpers, a lady living in the Native Territories, sends me a lot of notes she made on the growth of the male cone of Encephalartos villosus, which are of great interest in this connexion.' She noticed a horrible smell when the sporophylls were open and caught several beetles. 'Perinquey has identified the beast; he says it belongs to what is considered to be the most ancient group of the Coleoptera-which sounds fascinating, but may, of course, mean nothing. Excuse this long scrawl. People here don't care much about these things, and I must inflict them on somebody.' In a later letter he spoke of evidence of insectpollination in Encephalartos Fredericki-Guilielmi: 'the more I see of the wool-enveloped cones the more impossible it seems that it can be pollinated by any other agency. The cones are all infested by the same kind of weevil as that which inhabits $E$. villosus. The development part of the work is a tremendous business. It seems to me that I ought to go on fixing and section-cutting about ten years before I write.... I returned last night from the Karroo and Cycad country, having had a very successful time. I had a most interesting three days with Encephalartos Fredericki-Guilielmi. It is coning freely now, and most cones when I was there were on the eve of pollination. As a result of a great number of observations I feel satisfied that in the case of a female plant cones are produced only once in six years, and very frequently a longer period intervenes.... As to coning, it looks as if the process taxes the plant very severely, so that it has to rest for some years before it can again attempt to produce cones. The first seed-bearing plants surely cannot have taken it out of themselves to this extent or they could never have left any descendants. Then it must be that these Cycads are a long way from the earliest Spermaphyta, and have developed on not very sound lines. One defect that suggests itself to me is that they produce 
far too many seeds for the size of the plant; for instance, one of these Encephalartos Fredericki-Guilielmi plants produces easily more than $\mathbf{1}, 500$ seeds in one season. When you think of the energy consumed in the rapid development of the cone... and the enormous quantity of carbohydrate stored away in the prothalli, you cannot wonder that the plant feels a bit done up when all is over. Is there any evidence of the existence of herbaceous Pteridosperms or Gymnosperms in Mesozoic times? If there have ever been such Gymnosperms, is it not strange that they have left no descendants of similar habit?... Yet the first vascular plants must have been herbaceous. What I have in my mind is the idea that the conditions which called forth the Cycads, for example, may have been entirely different from those at present prevailing and quite unsuitable for the existence of small perennials and annuals. Suppose, for example, a set of conditions which resulted in rapid and luxuriant growth. Then the Cycads of to-day might be the struggling posterity of a race of giants, preserving under adverse conditions the prolific reproduction of forbears which could afford such generous habits without endangering their existence thereby. But I must not worry you any more. These Cycads are most fascinating things, and they grow upon one. In the Eastern provinces I am rapidly acquiring a reputation for incipient imbecility, for I am told that there never before was any one in South Africa who would spend four days in the train in order to spend three days among the Palms.' Early in 19I 5 he wrote: 'I do wish you could see my Cycads. The slope [in the National Garden] which, when you were here [July, I914], harboured one specimen of Encephalartos Altensteinii, now holds 300 plants, representing possibly all the known and one hitherto unknown South African species.' It was near to this slope that Pearson was buried on November 4, I9I6.

Shortly after his arrival in Ceylon Pearson wrote: ' $I$ am at work on the patana flora up country. It is far more interesting on the spot than on paper. The patana looks very uninteresting from a distance, as nothing shows but $R$ hododendron arboreum and a rough tussocky grass; but it really bears a fairly rich flora, composed almost entirely of xerophytic plants.' Several attempts had been made to explain the occurrence of a comparatively barren country occupied by the savanna-like patanas at approximately all altitudes over $2,000 \mathrm{ft}$., in the midst of a luxuriant subtropical vegetation; but much more information was needed. At the suggestion of the Director of the Peradeniya Garden (Dr. J. C. Willis), Pearson undertook the task of discovering the causes which led to the development of the flora. He concluded that the peculiarities of the climate have co-operated with periodically recurrent grass-fires in transforming an open forest into barren grassy plains. His results include an enumeration of the species collected, an account of their biological characters, and an interesting examination of the factors concerned in producing the xerophilous 
character of both the wet and dry patanas, that is, the vegetation above and below $4,500 \mathrm{ft}$. In the joint paper with his friend $\mathrm{Mr}$. J. Parkin the conclusions given in the first account, which were based on field observations, are tested by a thorough anatomical investigation. It was found that the peculiarities which usually characterize plants of insolated areas are not more strongly developed in members of the dry flora than in the plants of the wet patanas-a fact probably due to the influence of the powerful monsoon winds, the functional activities of the roots being also lowered by the humic acids in the soil. The Ceylon visit introduced Pearson to a new world which he thoroughly enjoyed, and by his apprenticeship to field-work in the wider sense he qualified himself for the later expeditions in South Africa which he conducted with conspicuous success.

A paper written at Kew deals with an inquiry, undertaken at the suggestion of Sir William Thiselton-Dyer, into the morphology and functions of the double pitchers of four species of Dischidia: this piece of work is exceedingly good considering that the material consisted entirely of herbarium specimens. He made full use of the time spent in the Herbarium to familiarize himself with the methods of systematic botany and, as the list of his publications shows, his output during that period was considerable. In later years he amply repaid the Royal Gardens by his gifts of material collected in South Africa. The collections sent to Kew included one of the finest series of succulents ever received in this country. The volume of the 'Botanical Magazine' published in 1910 is dedicated to Professor Pearson, 'as successful in his leadership of Botanical expeditions as he has been generous in distributing their fruits'. The Botanic Garden of his old University has also greatly benefited by his many contributions, and a word of acknowledgement is due to $\mathrm{Mr}$. Lynch, the able Curator, for the skill with which he cultivated Welwitschia and other plants received from Pearson.

Soon after his arrival at the Cape Pearson set himself the task of continuing the investigation of Welwitschia, so splendidly inaugurated by Sir Joseph Hooker. In May, I904, he wrote from Cape Town: 'A year and a week since I arrived in the land of sunshine, dust, and politics, and yet this is the first time I have set myself to write to you.... I started last year with eleven students. This year I have twenty-two.... The Council is putting me up a splendid laboratory which I shall not be ashamed to show you when you come out.... I thought of you a good deal in January last, when I spent two glorious days in the heart of the Damaraland desert in the company of the most magnificent array of flowering Welwitschias that ever man saw. You must know that when I was first appointed here I had a dream, the purport of which was that Welwitschia was delivered into my hands. And sure enough without any particular effort on my part I found myself in Welwitschia-land, and hoped to spend some weeks there. Fate, however, determined otherwise. The Hereros and the Germans came to 
blows, and between the two of them I had a lively time of it. I was lodged in a German military station, which I had to quit in haste. I hear that a few days only after I left the station ceased to exist.' A second expedition was planned in 1906. He wrote in September of that year: 'The Welwitschia trip is, I hope, fixed up. The Governor of the territory seems quite keen on my going again.' In the same letter he made a suggestion which might with advantage be taken to heart by the governing bodies of Universities. ' $I$ am expecting to take my year's leave in 1908. Unfortunately I have to come on half-pay and shall have to economize. I must come, however, by some means as I am getting stale. They give us the sixth year off as a favour, on half-pay. I lose no opportunity of pointing out that in their own interests they ought not only to make it easier for us to take the leave, but to insist that we do take it. I don't think one can stay here continuously for more than five years without deterioriating.' In February, I907, he wrote: 'I and my collections landed this morning. I hope the trip has been entirely successful. Here I think I have established a record. The Swakop river-bed swarms with game, and therefore the leopard is fairly common at Hadjamchab-so common that the sergeant in charge of the station considered it quite unsafe to go out at night without arms, and indeed did not like me doing so during the day. So on two nights when I made expeditions to Welwitschia I was escorted by two men armed to the teeth, and you may imagine me sitting on the sand in the moonlight, with a bottle of chromacetic acid between my knees, dissecting female cones while the two warriors stood at attention behind me... The German Government treated me with extraordinary kindness and generosity, they cabled instructions from Berlin to aid me as far as possible, and this they certainly did. . . . I have already told you they invited me to Windhuk.' In the latter part of ${ }^{1} 9^{1} 5$ he was invited to the same place by General Botha, and wrote on January II, I9I6, from the head-quarters of the Union forces: 'I arrived here to-day after a rather arduous journey of five weeks' duration through what is botanically an exceedingly interesting country. In the course of it I have seen what I have long wished to see, viz. the edge of the Welwitschia desert. In fact, I have been able to trace the change in the flora from the Kalahari plateau right into the desert. Until my collections are worked out I cannot quite see whither I am being led, but I think I can now more or less co-ordinate many odd facts I have been accumulating in the course of these journeys, and at least show the relation between the desert flora and those surrounding it.... The work this time has meant a journey through some most difficult places. Both my wagons broke, though fortunately we were able to bring them both to the end of the 410-mile journey.... On another occasion we had to travel all one night to reach the next water, and in the course of it we crossed the same rocky riverbed no less than twenty times. . . However, it is something to feel that one 
has been through it and has brought everything except two out of the team of thirty donkeys to the end of the journey.... I asked one of the Bastard Hottentots, who has now been under German government for years, what he thought of the Germans. He said they are "the worstest people under the sun "- and the Bastard has some reason for thinking so.' In a letter to Prof. Herdman (published in 'Nature', March 2, I9I6), written after his return to Cape Town, on January 28 , Pearson referred to his journey through the semi-independent territory of the Bastard Hottentots, adding, 'No German dare venture into it, but when the people found I was English they could not do enough for me'.

Perhaps the most interesting of the many results of his researches on Welwitschia is the discovery of the nature of the 'endosperm'. 'I am now more than ever certain that the plant [Welwitschia] stands at the top of a series-I fear on a giddy pinnacle whose sides are so steep that there is no telling how it got there.' In a later letter he says: 'I am nearly converted to your view of the possible relationship between the Gnetaceae and Angiosperms. The Welwitschia endosperm has quite altered my point of view. I am going to try and prove that the Welwitschia endosperm is homologous with that of the Angiosperm, and, further, that it belongs neither to the gametophyte nor sporophyte generation, but is a structure sui generis. ... I must get hold of Gnetum africanum. If I can't get the money for the whole trip of which I sent you an outline scheme... I hope I shall at least be able to obtain, say, £100 to enable me to go to Quetta, where the Gnetum grows.' A substantial grant from the Trustees of the Percy Sladen Memorial Fund enabled him to carry out the scheme in 1908-9.

In the earlier stages of development the embryo-sac of Welwitschic contains numerous free nuclei: this condition is followed by partial septation, which produces a tissue of multinucleate compartments. In the upper part of the embryo-sac each 'cell' has I-2 nuclei, and later as many as 5 , while in the lower part of the sac each 'cell' has 2-12 nuclei. The 'cells' with 2-5 nuclei in the micropylar region of the embryo-sac produce embryo-sac tubes which grow up towards the descending pollentubes. On March 3, 1908, he discussed the question of nomenclature with regard to the 'endosperm': 'In Gnetum and Welwitschia the embryo-sac becomes filled with nuclei, all of which are probably capable of being fertilized, i.e. all are potential gametes. Of these a few are functional. The remainder, or most of them, fuse in groups of $7,8,9$, 10, or more, and form a number of fusion-nuclei which I believe to be homologous with the definitive nucleus of the Angiosperm. These fusion-nuclei on division give rise to a tissue whose later growth is considerable, and is so highly organized that the tissue (endosperm) must be regarded as an organism. This organism is not in the direct line of the life-cycle and belongs neither to the sporophyte nor to the gametophyte. Now as the term endosperm is physiological (accord- 
ing to its author's definition) and applies equally to the prothallus of Pines and to this endosperm of Welwitschia and the Angiosperm, I want a morphological name for my new organism. I propose to call it the Trophophyte.'

The Welwitschia work naturally led to an attack on Gnetum, and one of the main objects of the Expedition of 1908-9 was to obtain material of Gnetum africanum from Angola. The first part of this journey was made in company with the Magnetic. Survey Expedition of the Carnegie Institute, under the leadership of his close friend and colleague, Dr. J. C. Beattie. On April 12, 1910, he wrote: 'I have both Gnetum africanum and G. scandens on the go, and I have cut about ten ovules of each.... While I am not yet able to prove it to the satisfaction of a sceptic I have myself no doubt that the endosperm [Gnetum] is formed as in Welwitschia (the attitude is, I am afraid, unscientific, but it is I think impossible to keep one's mind open until the proof is complete).' In November, 19I5, he added: 'I have at last settled the question of the resemblance of the endosperm [of Gnetum] to that of Welwitschia; it is formed in exactly the same way, which pleases me mightily.'

Prof. Pearson consented to contribute a volume on the Gnetales to the 'Cambridge Handbooks', edited by Mr. Tansley and myself, and this work may, we hope, be far enough advanced to be published. In a letter dated April 20, 1916, he wrote: 'A large part of the book on the Gnetales is written, though it will need some revision.... As to the GnetaleanAngiosperm alliance, there must be one, I think, but at present I cannot bring myself to believe that it is direct. If they are not connected that endosperm wants a lot of explaining. The trouble is that I cannot make head or tail of the flower, and the relation between Ephedra and the others is extremely puzzling. The latter is probably very simple if we only had the key-the former I dream about, so far unsuccessfully. As to Bennettites, I think I made far too much of the idea of a relationship in I909, but I have not given it up yet. The more we know about the group the more difficult it seems to become.' In a later letter he made an interesting suggestion about the comparison of the Gnetales and the Bennettitales. 'I am bothered by my ignorance of Bennettites. I have never seen a section of a flower and the idea I have been harbouring for some time is very probably absurd. It is about that interseminal scale, the real nature of which, so far as I can make out, no one seems to understand. In my ignorance I have wondered whether it is really a "scale" at all.' He suggests that the interseminal scale 'may be something of the nature of the thick cushion of Gnetum.... If you have a large number of ovules arising in crowded whorls or spirals from an elongated conical axis, and sunk in the tissue of the axis, as are the young ovules of Gnetum africanum, it seems to me that transverse and longitudinal sections might give very much the appearance of such sections of Bennettites.' 
Reference has already been made to Pearson's success as an explorer. The liberal grants from the Percy Sladen Memorial Trustees, who had complete confidence in his proposals, from the Royal Society, and from other sources led to results of exceptional importance-morphological, systematic, phytogeographical, and ecological. Pearson's success was due to his tactful persistence in the face of obstacles, his infectious enthusiasm, a sense of humour, his all-round training, and keen powers of observation. On all his journeys he took with him Lamb's 'Essays' and generally small volumes of Shakespeare's plays.

Before the final arrangements for his most important expedition were complete, Pearson wrote: 'On Saturday night I had a long talk with Dernburg in his bedroom at Government House. Did you ever discuss the situation with a European diplomatist in his bedroom? The [German] Imperial Government is most anxious that the country lying north of Windhuk ... should be botanically examined with a view to its agricultural development.... I at once offered to go if the Government would organize the expedition and take me there and bring me back again. Dernburg accepted the offer on the spot. I asked for no remuneration and none was suggested.' Two months later he added: 'I am not quite sure, but I believe that the Dernburg proposal is off.' Shortly before leaving Cape Town Pearson wrote: 'The Sladen Trustees have most kindly left me free to take either route from Windhuk. Unless the obstacles are serious I shall adhere to the Angola plan. Through Sir Donald Currie I have received a most cordial letter of introduction from the Portuguese Minister of Marine and the Colonies to the Governor-General of Angola. Furnished with this and with a formal letter from Sir Hely Hutchinson I am certain to receive every possible attention (probably to an embarrassing extent) and assistance from the authorities.' He left Cape Town in November, 1908, and early in December reported progress from Calvinia: 'I have just removed the stain of twelve days' travel and had a more or less civilized breakfast. The first stage of the trip has been fairly arduous, as we have crossed the north-east corner of the Karroo, which this year is nearly as arid as the German desert.... I am sending nearly 300 species to Cape Town from here (you see I am in a fair way to become a real botanist and bundles of dried specimens are beginning to impress me greatly)-but seriously it is intensely interesting to follow the changes in the flora over a long-distance journey such as this.' From Seeheum in German South-West Africa he complained of suffering from 'another bout of hospitality which is if anything more killing than the English. ... I estimate that since I started I have collected about I,200 species, the majority of which are safely housed in Cape Town by this time. .. By the way, I found living in a tent about $100 \mathrm{~km}$. south of this place an old Irish lady who has a most vivid recollection of Galton, whom she saw at Rehoboth when he visited this country in the fifties. 
She seemed quite confident that Galton will still remember her, and begged me to give him a message from her. Her name is Mrs. Bassingthwaite... . The flies and the temperature are both fairly beyond words. I suppose this country is destined to become a colony some day, but the native question must be solved first. I fancy that what is necessary is a thorough study of the subterranean watercourses throughout the whole of South Africa.'

Pearson had many stories of amusing incidents on his journeys. One of his colleagues in the South African College writes: "It was a treat, for instance, to hear him tell in his unique way the story of the old storekeeper with whom he had stayed a couple of days and become friendly. This man had two sons and was obsessed with the necessity of fixing up their careers. He would like to consult the Professor. The elder was a really clever fellow; in his case there would be no difficulty, he naturally would go into business. But the trouble was the second. He was a very decent boy, but a bit dull-yes, dull; he would be no good at business. It is good to recall the twinkle in Pearson's eyes and the laughter in his voice when he described the old man's trouble and the evident beating about the bush, and finally his blurting out quite seriously, "Couldn't you tell me how to make him a professor like you?"'

The visit of the British Association to South Africa in 1905 was an event which gave great satisfaction to Pearson; he was justly proud of his department and enjoyed showing it to his visitors. He played no small part in contributing to the success of the meeting, which is associated in my mind with memorable days spent with him and his wife in their Kenilworth home.

Of the many services rendered by Pearson to Science perhaps in some respects the part he played in the establishment of the National Botanic Garden ${ }^{1}$ is the greatest. It is a splendid memorial of a botanist whose explorations enormously extended our knowledge of the richness of the floras of South Africa, and who by his manifold activities and sound common sense succeeded in demonstrating to the layman the value of botanical research. There can be no doubt that the credit for this addition to the efficiency of the Empire is mainly due to Pearson, though he would not admit that he was entitled to more than a comparatively small share in the events which led the Government to take the final step. The project was first put forward in a concrete form in his Presidential address before Section $\mathrm{C}$ of the South African Association for the Advancement of Science in I9IO. He advocated concentrated action by the South African Colonies with a view to the full development of their unrivalled botanical resources, and formulated a scheme worthy of a many-sided and far-sighted botanist. The Garden should be a centre of botanical activity in the widest sense ; it should be concerned with

1 For a fuller account of the Garden and its inception and establishment the reader is referred to the Kew Bulletin, 1913, p. 309, and to the Gardeners' Chronicle, August 30, 1913, p. I5I. 
botanical exploration, the cultivation of indigenous plants, and experimental work. He dwelt on the neglect of the native plants and stated that more South African species are cultivated in European gardens than at the Cape. The Garden should include a National Herbarium, a Museum of Economic Botany, a Library, and Research laboratories. He emphasized the importance of grasping the fundamental truth that the true springs of South African development are within and not oversea. The Garden should also be an 'expression of the intellectual and artistic aspirations of the new nation whose duty it is to foster the study of the country which it occupies, to encourage a proper appreciation of the rare and beautiful with which nature has so lavishly endowed it'. In an article on a 'State Botanic Garden', while advocating the importance of economic questions, Pearson urged the importance of pure science: 'problems which appear to be of merely academic interest to-day may be of unmeasured practical importance to-morrow.'

In reply to a request for a statement as to his share in the foundation of the Garden, Pearson wrote on March I8, I9I4: 'I do not really think I can say what has been my share in the formation of these Gardens. I dare say they would not have been in existence just now but for my address to the South African Association in I910. But since then a good many people have been prominent in the movement. ... Having been fairly constantly in the fray for three years, I do not think I am well able to judge how much each of us contributed towards the result, and I fear that I should be more likely to exaggerate the importance of my own efforts than those of any one else.' On April I6, 1912, he wrote: 'I have got the Botanic Garden movement going strong just now. We have [to send] a deputation to the Prime Minister and he asks for a minutely detailed scheme. The site I have chosen (and which the Committee has approved) is a fine estate, $32 \mathrm{I}$ acres in extent, belonging to the Government (a part of the Rhodes estate), and now for many years derelict and unused. For the purpose of a Botanic Garden it could hardly be better suited.'

On October 6, I9I2, after referring to a projected expedition, he adds : ' I am longing to get away for a time from this teaching grind, which is gradually wearing away my soul-this expression probably reflects but a passing mood. In any case, the top of the Karasberg cannot but be delightful.'

On May 22, I9I3, he reported further progress with the Garden: 'I sent you a paper containing an account of the Botanic Garden debate [in the House of Assembly]. Since then Sir Lionel Phillips has kept things going, and to-day the end has been gained.... The success is entirely due to Phillips - a man of extraordinary energy and enthusiasm.... I am therefore to some extent identified with the scheme. A botanist must run it from the beginning if it is to be a success. At first it will be 


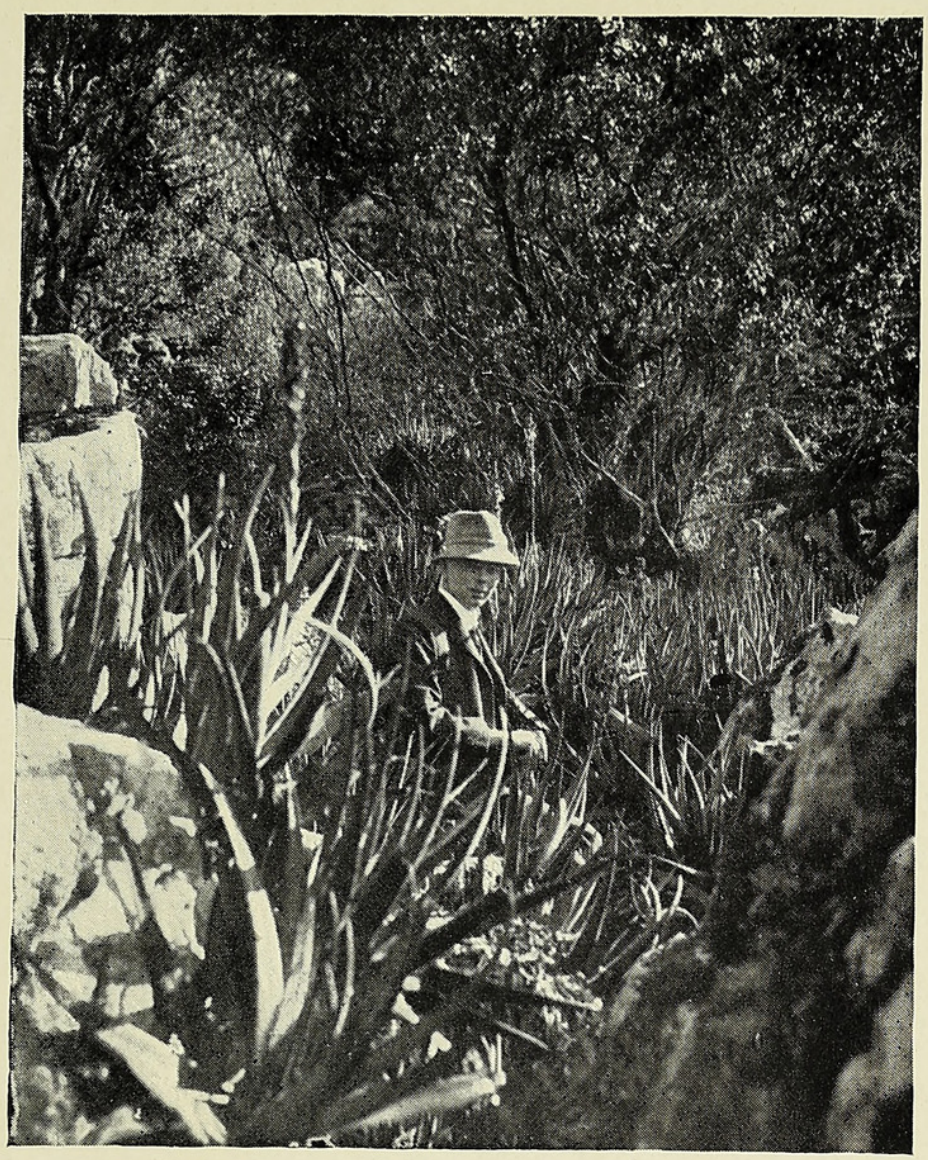

H. H. W. Pearson in the Kirstenbosch Garden: Aloes in the foreground. A.C.S. Photo. July 20, I9I4.

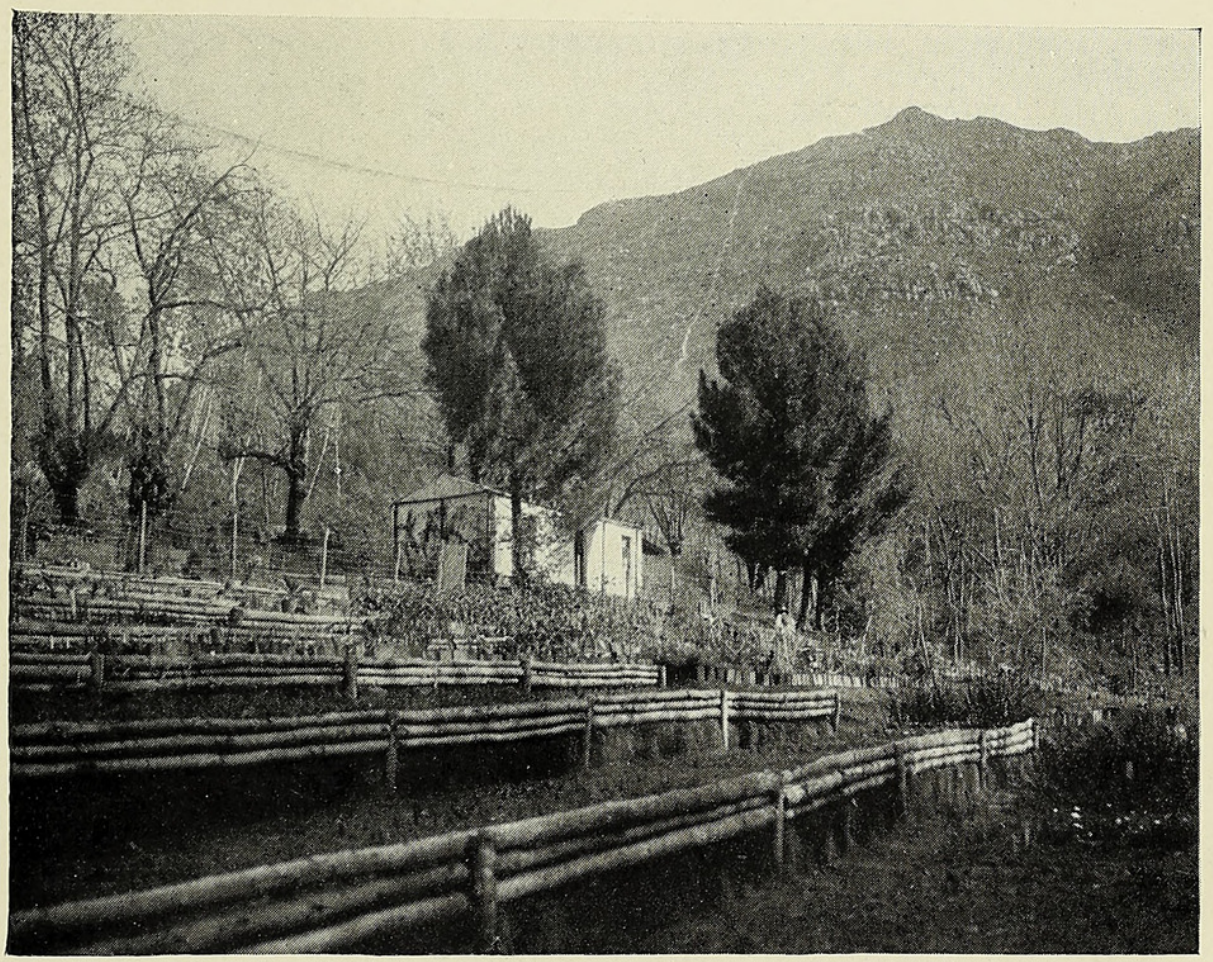

Temporary Office and Plant Nurseries, Kirstenbosch. A.C.S. Photo. July 20 , I9I4. 

impossible to provide a salary for such a botanist. There is no other one who is in a position to take charge of it without payment. If I don't do it the South African Botanic Garden collapses for the time being. Circumstances are therefore too much for me and, though at no little personal sacrifice, I must undertake it. It will not entail my giving up my own line of work (at least it shall not), but it must interfere with it to some extent. But my own view is that if I can establish a Botanic Garden here on a sound basis I shall do more for Botany than by writing an extra paper or two. It may not be so good for myself, but that is, I hope, beside the point. I have been carried on almost involuntarily and have persuaded myself that I am acting rightly.... Since I wrote to you the Council has given me a second Lecturer.' In July of the same year he wrote: 'As to the Directorship-there is at present no money available for a botanist, and I can do the place a greater service by doing what little I can in an honorary capacity than if I became a salaried officer.... I feel that the thing has come upon me unsought and I have no choice but to take it up. It will be a burden, but it is worth carrying if it never falls to me to exploit its contents.' The author of an appreciative and sympathetic article in the 'South African College Magazine' in describing Pearson's work for the National Garden writes: 'He never fully appreciated the value of his own enthusiasm and manner; and I remember the doubts which assailed him as the last attack-in a fight which he knew had been fought and lost many a time in the previous forty years-progressed and the unalloyed joy he experienced when at last he saw the Garden established.'

Pearson was appointed Honorary Director and began his duties on August I, I9I3. The last time I saw him was on July 20, I9I4. The Director's house was nearing completion and the plant-nurseries (Plate) were well stocked with material received from various parts of the Dominion. From a wet glen in which were several plants of the South African Fern Hemitelia capensis we climbed up a rocky slope, on the summit of which Aloes were flourishing (Plate) in a habitat sharply contrasted with that below, and from a still higher point we looked across a forest of Silver-trees (Leucadendron argenteum) and beyond to the shores of the Cape Peninsula, a view that it would be hard to match in any other Garden.

The following notes, for which I am indebted to Mrs. Pearson, show how he spent his days as Director and Professor: ' He so arranged his work at the South African College that he was able to devote Wednesday, Saturday, and Sunday to the Gardens. On the other days he left home at $7.45 \mathrm{a}$.m. summer and winter, driving himself to the station in all weathers, a distance of $2 \frac{1}{2}$ miles, and usually returned home at 5.30 p.m. After tea he walked round the Gardens inspecting work and arranging various matters with the Curator and Ranger. His evenings were spent in attending to 
Garden correspondence, writing up research notes, reading scientific periodicals, and finishing the day with some book on the war. On Wednesday, Saturday, and Sunday he began the day with a ride before breakfast and devoted the rest of the morning to the Gardens. With the help of a coloured labourer he arranged and planted all the Cycads. The design and construction of all new work he thought out while wandering over the estate and imparted his ideas to the Curator who drew up plans for his approval.'

During his brief tenure of the Directorship he gave himself unsparingly to the work of construction, and the impression left on my mind after our tour of the Garden was that under his guidance Kirstenbosch would in course of time rival the best Gardens in the world. As the author of an obituary notice in the 'Cape Argus' says, 'he threw his whole soul' into the business of founding the National Garden and 'carried out a work which will live for ever and which may be regarded as one of the treasures of South Africa'. His burial-place, to quote from the 'Cape Times', 'faces the slope with the Cycad plantation, the one little section of his plans which, in the short time vouchsafed him, he was able to bring near completion'. The funeral service, in which the Archbishop of Cape Town took part, was held in the Protea church close to the Garden.

A few months after I saw Pearson in Cape Town he wrote to me about the condition of affairs in South Africa, showing his usual grasp of the political situation, and added: 'Botha's action has been magnificent and has had a great effect. Even I have volunteered for any work they choose to put so useless a person to.' And in April, I9I5, 'I have felt a little easier in my mind since I volunteered for local defence. I am now enrolled as a mounted infantryman, my official title being "Trooper Pearson", which gives me some measure of satisfaction.' Pearson was one of the guard of honour when General Botha returned from the conquest of German South-West Africa.

The range of subjects illuminated by Pearson's researches is shown by an inspection of the Bibliography. His contributions to the morphology and reproduction of the Gnetales have a special significance both from the point of view of their great interest to botanists and as illustrating his skill as an investigator and his power of grappling with particularly difficult problems. As a systematist he held a high position: his earlier papers written at Kew deal with plants from many regions, and the fact that he was invited to describe the Verbenaceae and the Thymelaeaceae in the 'Flora Capensis' and the 'Flora of Tropical Africa' respectively shows that his ability in this branch of the subject received due recognition. His later papers on systematic botany are concerned chiefly with the rich material collected by himself. Pearson gave special attention to the examination of the desert flora of South-West Africa, particularly from the point of view 
of its relationship to the floras of neighbouring regions. One of his aims in visiting the Karasberg range, which rises from the level plateau of the Kalahari desert, was to search for clues to the past history of the South African flora. He always arranged his routes according to a well-considered plan of attack upon the phytogeographical questions suggested by the different types of vegetation and the varied physical conditions of the countries through which he travelled. Had Pearson lived a few years longer there is no doubt he would have worked up his field-notes into a connected whole, and knowing how well qualified he was by training and by his ability to see things in their true perspective, one is able to realize to some extent how valuable such a digest of his knowledge and mature experience would have been.

His thorough treatment of the problems presented by the rootparasite Striga lutea, a Scrophulariaceous plant locally known as the Rooibloem or Witchweed, which causes serious loss to cultivators of Maize, and the valuable practical directions for dealing with the disease afford further evidence of his versatility and of his desire to demonstrate the importance of Botany as an applied science. With the assistance of Miss Stephens, one of his pupils, he studied the details of the haustorial structures and their connexion with the host; he also investigated the germination and dispersal of the small seeds and made many experimental trials of different methods of dealing with the pest. Previous attempts to germinate the seeds of Striga had been unsuccessful and Pearson proved that germination occurs only in presence of the host.

During a halt in Namaqualand Pearson made observations on the internal temperature of Euphorbia virosa and Aloe dichotoma. He found that Euphorbia, with its large chambered pith, responds more quickly than the Aloe to changes in the external temperature and attains higher maxima. He also investigated the effects of wounding: in Aloe the lowering of the internal temperature is due to evaporation at the surface of water conducted through the xylem, while in Euphorbia the lowering is due in part to surface evaporation, but also to the expansion of gases imprisoned in the pith.

In answer to a request for a few words about our friend the High Commissioner in London for British Suuth Africa, the Right Hon. W. P. Schreiner, wrote as follows: 'I don't think that I can really add anything that is not better said by others about dear Pearson. I entirely associate myself with what is written of him in prose and poetry in an article in the "South African College Magazine" for November, 1916, where he is placed at the front of the Roll of Honour. My abiding impression of him is of a shining bright personality. His laugh was a tonic. He was the most cheery man at cheerful gatherings such as our remote Oxford and Cambridge dinners on Boat-race night, or at the annual College feasts at Cape Town. But 
his work and purpose were never lost sight of, and he won his way not only to our hearts but also to our pockets for the big object which he accomplished. He was a boy among men, but a greatly respected man among his boys and girls at College. By none more than by his friends and students in South Africa is his loss deplored.'

Harold Pearson was a high-minded student and a loyal citizen whose short life was spent in the service of Science and who laboured to the utmost of his capacity for the good of the country of his adoption. By his devotion to duty and his suppression of self in his dealings with all sorts and conditions of men, he gained not only the affection of those with whom he was associated, but he exerted a very wide influence. His life recalls Hazlitt's words: 'When the pursuit of truth has been the habitual study of any man's life, the love of truth will be his ruling passion.' $\mathrm{He}$ enriched the world by deed and example; his pioneer work has made the path smooth for those who follow him, but it will be their responsibility and privilege to do their best to maintain the high standard represented by Pearson's work for Botany and for the common life of the Colony. As the author (W. Duncan Baxter) of an In Memoriam article in 'The Cape' truly says: "The best memorial that can be raised to him is to see that his work at Kirstenbosch is carried on, and the National Botanic Gardens made what he pictured them in his mind's eye. That is the way to perpetuate his memory, for as long as Kirstenbosch exists, there will be linked with it the name of its founder-the scholar and gentleman, Harold Pearson.'

I cannot close this inadequate account of one of the most lovable men it has been my good fortune to know without a word of sympathetic reference to the devoted wife who shared his South African life. Though all botanists mourn the premature death of an able colleague and many are the poorer for the loss of a true friend, she, whose loss is the greatest, may derive some consolation from the knowledge that her husband's services were very widely and very sincerely appreciated.

\section{BIBLIOGRAPHY.}

1898. Anatomy of the Seedling of Bowenia spectabilis, Hook. f. Ann. Bot., vol. xii, p. 475.

1898. Apogeotropic Roots of Bowenia spectabilis, Hook. f. Rep. Brit. Assoc. Adv. Sci., p. 1066. 1899. The Botany of the Ceylon Patanas. I. Journ. Linn. Soc. (Bot.), vol. xxiv, p. 300.

1900. Cochlearia Hobsoni, Pearson. Hooker's Icones Plantarum, vol. xxvii, pl. 2643.

1900. Hemsley, W. Botting, and H. H. W. Pearson. Die botanischen Ergebnisse in Sven Hedin's Geographisch-wissenschaftliche Ergebnisse meiner Reise in Zentralasien 1894-7. Petermann's Mitteil., Ergänzungsband xxviii, p. $37^{2}$.

1901. Geophila pilosa, Pears. Hooker's Icones Plantarum, vol, xxviii, pl. $269 \mathrm{I}$. 
1901. Cuscuta hygrophila, Pears.; Vitex mooiensis, Pears.; Pentaphragma albiflorum, Pears. Ibid., Pls. 2704-6.

1901. The Verbenaceae of South Africa. Flora Capensis, vol. v, sect. i, pp. 180-224.

1901. Hemsley, W. Botting, and H. H. W. Pearson. On a Small Collection of Dried Plants obtained by Sir Martin Conway in the Bolivian Andes. Journ. Linn. Soc. (Bot.), vol. xxxv, p. 78.

1901. On some Species of Dischidia with Double Pitchers. Ibid., p. 375.

1901. Description of Clerodendron Curtisii. Kew Bulletin, Nos. I72-4, p. I42.

1901. Hemsley, W. Botting, assisted by H. H. W. Pearson. The Flora of Tibet or High Asia, being a Consolidated Account of the Various Tibetan Botanical Collections in the Herbarium of the Royal Gardens, Kew, together with an Exposition of what is known of the Flora of Tibet. Ibid., p. I 24. [On p. I 24 there is the following note: 'It should be explained that Mr. Pearson was joint author of this paper in the form it was first presented to the Society, but in consequence of a change in his appointment he was unable to take part in the additional work involved in reconstructing it on the present plan.']

1903. Article, 'Palestine' (I 4 b Flora). Encyclopaedia Biblica (Cheyne and Black), vol. iii, p. 354r.

1903. The Double Pitchers of Dischidia Shelfordii, sp. nov. Ann. Bot., vol. xvii, p. 6 I 7 .

1903. The Teaching of Botany. Rep. S. African Assoc. Adv. Sci. (Cape Town), p. 3 I 2.

1903. Parkin, J., and H. H. W. Pearson. The Botany of the Ceylon Patanas. II. Journ. Linn. Soc. (Bot.), vol. xxxv, p. 430.

1905. The Systematic Position of Welzritschia. Brit. Assoc. Adv. Sci. Report (South Africa), p. 590. 1905. Some South African Verbenaceae. Trans. S. African Phil. Soc., vol. xv, p. I 75.

1906. Some Observations on Welwitschia mirabilis, Hook. f. Phil. Trans. R. Soc., vol. cxeviii, p. 265 .

1906. Notes on some South African Cycads (Abstract). Rep. S. African Assoc. Adv. Sci. (Kimberley), p. 260.

1906. Some South African Cycads; their Habitats, Habits, and Associates. Brit. Assoc. Adv. Sci. (York), p. 738 .

1906. Notes on South African Cycads. I. Trans. S. African Phil. Soc., vol. xvi, pt. iv, p. 34I.

1906. Descriptions of Connaropsis acuminata, Pears., Cuscuta Upcraftii, Pears., Euthemis ciliata, Pears., Semecarpus cinerea, Pears., and Swintonia puberula, Pears., Kew Bulletin, No. I, pp. 2-5.

1907. The Living Welwitschia. Nature, April 4, p. 536.

1907. Some Observations in the Welwitschia Desert. Rep. S. African Assoc. Adv. Sci. (Natal), p. II6.

1907. A Botanical Excursion in the Welwitschia Desert. Brit. Assoc. Adv.Sci. Rep.(Leicester), p. 685.

1907. Interim Report of the Committee: Research on South African Cycads and on Welwitschia. Brit. Assoc. Rep. (Leicester), p. 408.

19.07. Some Notes on a Journey from Walfish Bay to Windhuk. Kew Bulletin, No. 9, p. 339 .

1908. A Note on the Morphology of Endosperm. Brit. Assoc. Rep. (Dublin), p. 9I4.

1909. Further Observations on Welwitschia. Phil. Trans. R. Soc., vol. cc, p. 33I.

1909. A Botanical Journey in South-West Africa. Gard. Chron., Dec. 4, I I, I8, pp. 369, 40 I , 4 I 4.

1909. Percy Sladen Memorial Expedition in South-West Africa, 1908-9. Nature, vol. lxxxi, pp. $466,499$.

1910. The Travels of a Botanist in South-West Africa (Percy Sladen NLem. Exped., I908-9; Rep. I). The Geogr. Journ., vol. xxxv, p. 48I ; map, p. 620.

1910. A National Botanical Garden. Presid. Address to Sect. C of the South African Assoc. (Cape Town). South African Journ. Sci., being the organ of the S. Afr. Assoc., vol. vii, p. 37.

1910. On the Embryo of Welwitschia (Percy Sladen Mem. Exped. SW. Africa; Rep. III). Ann. Bot., vol. xxiv, p. 760.

1910. Welwitschia mirabilis. Gard. Chron., vol. xlvii, p. 49.

1911. A State Botanic Garden. The State of South Africa, May, I9I I.

1911. Harry Bolus, D.Sc., F.L.S. (I834-I9II). The African Journ. Sci., vol. viii, p. 69.

1911. On a Collection of Dried Plants obtained in South-West Africa by the Percy Sladen Mem. Exped., I908-9 (Rep. V). Ann. S. African Mus., vol. ix, p. I.

1911. Rooibloem. (A Preliminary Report on an Investigation of the Life-history of the Rooibloem or Witchweed.) Agric. Journ. Union S. Africa, vol. ii, p. 266. 
1911. Through Little Namaqualand with the Vasculum and the Camera. Gard. Chron., vol. 1, pp. 6I, I2I, I66, I90, 200.

1912. On the Microsporangium and Microspore of Gnetum, with some Notes on the Structure of the Inflorescence (Percy Sladen Mem. Exped. SW. Africa, 1908-9; Rep. XV). Ann. Bot., vol. xxvi, p. 6o3.

1912. On the Rooibloem (Isona or Witchweed). Agric. Journ. Union S. Africa, vol. iii, p. ${ }_{5} \mathrm{I}$.

1912. Itinerary of the Percy Sladen Mem. Exped. to the Orange River, I9IO-II ; Rep. VII. Ann. S. Afr. Mus., vol. ix, p. 2 I.

1912. Le Vaillant's Grotto at Heerenlogement (Percy Sladen Mem. Exped. SW. Africa; Rep. XVII). The Geogr. Journ., vol. xxxix, p. 40.

1912. Pearson, H. H. W., and Edith L. Stephens. List of the Plants collected in the Percy Sladen Mem. Exped., I908-9, I9I0-I I ; Rep. VIII. Ann. S. African Mus., vol. ix, p. zo. [Subsequent Reports published in the Annals of the S. African Mus. were drawn up by the staff of the Bolus Herbarium and other workers under Prof. Pearson's superintendence, but published under their names.]

1913. List of Plants collected in the Percy Sladen Mem. Expeditions, Rep. XXVIII. Note on the localities visited by the Percy Sladen Mem. Exped. to the Khamiesberg, Giftberg, and Oliphant's River Mountains, Sept. I9II. Ann. S. Afr. Mus., vol. ix, p. I 29.

1913. The National Botanic Garden. Gard. Chron., Aug. 30, p. I 5 I.

1913. Thymelaeaceae. Flora of Tropical Africa, vol. vi, p. 2 I 2.

1914. The Problem of the Witchweed. Agric. Journ. Union S. Africa, vol. vi, p. 803.

1914. Observations on the Internal Temperatures of Euphorbia virosa and Aloe dichotoma (Percy Sladen Mem. Exped., Rep. XXI). Ann. Bolus Herb., vol. i, pt. ii, p. 4 I.

1914. On the Flora of the Great Karasberg (Percy Sladen Mem. Exped., Rep. LXIX). Ibid., pt. i, p. I.

1915. The National Botanic Garden. (Pamphlet.)

1915. A Note on the Inflorescence and Flower of Gnetum. Ann. Bolus Herb., vol. i, pt. iv, p. I52.

1915. Notes on the Morphology of certain Structures concerned in the Genus Gnetum. Trans. Linn. Soc., vol. viii, p. 3 II.

1915. Communication on the experimental use of plants for fixing moving sand. Minutes of Proc. South African Soc. Civil Engineers, p. 268.

1916. Exploration in South-West Africa. A Letter to Prof. Herdman. Nature, March 2, p. 4.

${ }^{1}$ On the Morphology of the Female Flower of Gnetum. Proc. R. Soc. S. Africa. [In the press.]

1 On some Stages in the Life-history of Gnetum. By H. H. W. Pearson and Mary R. H. Thomson. Trans. S. Afr. Phil. Soc. [In the press.]

1 For these titles I am indebted to the kindness of Mrs. L. Bolus. 


\section{$2 \mathrm{BHL}$ Biodiversity Heritage Library}

Seward, A C . 1917. "H. H. W. Pearson, F.R.S., SC.D. (Cambridge) [Obituary]." Annals of botany 31 , i-xviii.

https://doi.org/10.1093/oxfordjournals.aob.a089637.

View This Item Online: https://www.biodiversitylibrary.org/item/232813

DOI: https://doi.org/10.1093/oxfordjournals.aob.a089637

Permalink: https://www.biodiversitylibrary.org/partpdf/320205

\section{Holding Institution}

Smithsonian Libraries

\section{Sponsored by}

Biodiversity Heritage Library

\section{Copyright \& Reuse}

Copyright Status: Not in copyright. The BHL knows of no copyright restrictions on this item.

This document was created from content at the Biodiversity Heritage Library, the world's largest open access digital library for biodiversity literature and archives. Visit BHL at https://www.biodiversitylibrary.org. 